\title{
IS THE SMALL GOD FIGURE IN THE SEAL IMPRESSION OF TUDKHALIYA IV, RS 17.159, MURSHILI II?
}

H. Kübra ENSERT

\begin{abstract}
Anahtar Kelimeler: Hitit $\bullet$ Ikonografi $\bullet \mathrm{Kral} \bullet$ Tanr1 $\bullet$ Kült Keywords: Hittite $\bullet$ iconography $\bullet \operatorname{king} \bullet \operatorname{god} \bullet$ cult
\end{abstract}

\begin{abstract}
The small god figure, embraced in the embracement scene of the Ugarit seal impression is neither Khattushili III nor a local ruler nor Tudkhaliya IV himself, the owner of the seal, but it should be his grandfather Murshili II deified after death. D U NIR.GAL is the protective god of Murshili II, Arnuwanda II and Shuppiluliuma I who are the ancestors of Tudkhaliya IV. Murshili II is mentioned in the cuneiform writing that borders the subject seal impression. Therefore the small god figure should be representing Murshili II.The written documents tell that also ancestral gods protect the kings. This explains the reason why the dead kings appear in god iconography on the seals. This small god figure and the like prove the existence of a certain Hittite king iconography of kings deified after death in the Hittite art.
\end{abstract}

The seal impression of Tudkhaliya IV (Fig. 1a), uncovered from Ras Shamra (Ugarit), is on a tablet that relates the divorce decree of Ammistamru, the King of Ugarit, and the daughter of Bentesina, the king of Amurru'. The poorly preserved cuneiform writing of two lines that borders the circular seal impression narrates the ancestry of Tudkhaliya $I^{2}$ as follows: The seal of Tudkhaliya, the great king; the grandson of Murshili, the great king, the hero; the son of Pudukhepa, the

\footnotetext{
1 Schaeffer 1956, 14, 16-20, 111ff, Fig. 24-26, Pl. III, IV.

2 Schaeffer 1956, 14, 16, Fig. 25.
}

great queen of Khatti and Khattushili, the great king of Khatti, the hero.

A winged sun disk with the double disks crowns the whole composition. Under the winged sun disk the name and the title of the owner of the seal appear in three lines, starting with the top as follows: The first line reads" "Tudkhaliya, labarna, the great king", the second line reads "Tashmi Sharruma, the great king", and the third line, again, reads

\footnotetext{
3 Alp 1998, 21; Van den Hout 1995, 558; Schaeffer 1956, $112 \mathrm{ff}$.

4 Alp 1998, 21-4.
} 
"Tudkhaliya, labarna, the great king" between two life signs ${ }^{5}$.

In line with the first and the second lines, above, a woman figure appears at the left side and an embracing scene of two male figures appear at the right side. Because of the hieroglyphic inscription with the woman figure she is thought to be a Sun Goddess $^{6}$ (probably the Sun Goddess of Arinna ${ }^{7}$.

Both figures in the above embracement scene are depicted in the god iconography whereas the embraced are always the kings in power as it is widely known with the cases of Tudkhaliya $\mathrm{IV}^{8}$ in relief 81 at Yazllikaya, and Muwatalli II $^{9}$ and Murshili III $^{10}$ in the aedicula seals.

The hieroglyphic inscription shows that the embracing god figure is ${ }^{\mathrm{D}} \mathrm{U}$ NIR.GAL, the mighty storm $\operatorname{god}^{11}$. The storm god embraces the small god and holds the mace on the shoulder with the left hand. The small god figure has only the lance resting on the left shoulder (Fig. 1b).

\footnotetext{
According to Börker Klähn - Börker $(1976,32)$ the signs mean 'life for Tudkhaliya'

Schaeffer 1956, 17, 114 ff.

Alp 1998, 21; Alp 2001, 173.

Bittel et al. 1975, Taf. 62.

Beran 1967, Taf. 12, 250a, 251a, 252a, Neve 1991, Abb. 28a, 30a; Gonnet 1990, Lev. I.

10 Neve 1991, Abb. 29a; Alp 2001, 174.

11 Börker Klähn - Börker (1976, Abb. 32 n. 102, 107, 114) indicate that the sign of the Weather God in the picture seems in the form of a triangle, and accordingly a new drawing of the seal impression is made. The hieroglyphic inscription of the Storm God reads as follows: dNIR.GAL = the Weather God of the Kigdom (Börker Klähn and Börker 1976, 34); the Mighty Storm God (DEUS) TONITRUS FORTIS (Van den Hout 1995a, 558); the Weather God, the Warrior (Alp 1998, 21) and the Mighty (the heroic) Storm God $=$ DU NIR.GAL (Alp 2001, 173).
}

Up to date the short god figure is identified by different titles such as a local ruler $^{12}$, Tudkhaliya IV $^{13}$ or Khattushili $\mathrm{III}^{14}$, the father of Tudkhaliya IV. This small god figure is considered to be Tudkhaliya IV due to the reason that in the seal impression it is the only figure without any identification inscription.

The most important element in the determination of the identity of the small god figure, should be the fact that it is ${ }^{\mathrm{D}}$ U NIR.GAL that embraces him.

The protective god of Tudkhaliya IV is god Sharruma, whom he is depicted with in the embracing scene on relief number 81 at Yazllkaya ${ }^{15}$. The protective divinities of Khattushili III, the father of Tudkhaliya IV are the Sun Goddess of Arinna, Storm God of Nerik and Ishtar of Samuha. The small god can not be Tudkhaliya IV or Khattushili III if it is considered that the embracing god is ${ }^{\mathrm{D}} \mathrm{U}$ NIR.GAL. According to the written documents ${ }^{D}$ U NIR.GAL is the protective god of Murshili II, Arnuwanda II and Shuppiluliuma I who are the ancestors of Tudkhaliya $\mathrm{IV}^{16}$. The small god figure should be one of these ancestor kings of Tudkhaliya IV, who are deified after death.

Tudkhaliya IV has, mostly, mentioned of his father Khattushili III, his grandfather, Murshili II and his grand grandfather

\footnotetext{
2 Börker Klähn - Börker 1976, 22, 32.

13 Schaeffer 1956, 16-17, 112; Akurgal 1964, 98; Hawkins 1990, 311-312 n. 48; Hawkins 1995, 19; Van den Hout 1995a, 558, n. 63; Alp 1998, 21; Alp 2001, 173; Savaş 2002, 118, n. 112.

14 Mayer Opificius 1989, 362.

15 Bittel et al. 1975, Taf. 62.

16 I thank Prof. Dr. Ahmet Ünal for his helps regarding the protective gods of the Hittite kings
} 
Shuppiluliuma ${ }^{17}$. Khattushili III and Murshili II are also mentioned in the cuneiform writing that borders the subject seal impression. However ${ }^{\mathrm{D}}$ U NIR.GAL is the protective god of Murshili II but not of Khattushili III. Therefore the small god figure should be representing Murshili II. ${ }^{\mathrm{D}} \mathrm{U}$ NIR.GAL is mentioned together with the Sun Goddess of Arinna in the Annals of Murshili $\mathrm{II}^{18}$. The depiction of these two divinities on subject seal impression is in support of the above determination.

In the Hittite Art there are also other king and prince depictions that look like this small god figure. In spite of the fact that these king and prince figures have similar features they are either qualified as those in power or as those that are defied in life or after death.

The dressing of these figures looks more like those of the Hittite gods ${ }^{19}$ rather than the warrior uniform ${ }^{20}$ of the king in the texts related with the cult. It may be concluded that the pointed hat was worn by both the kings and the gods since Khattushili III is depicted with the pointed hat at Abu Simbel ${ }^{21}$. However the lack of the horn with the hat is important. Because the most important divinity sign is the horned hat in both Anatolia and Mesopo$\operatorname{tamia}^{22}$. Therefore these figures should be the figures of the kings and princes deified after death, but not of those in life. As to the kings deified while in life, they

\footnotetext{
17 Van den Hout (1995a, 557) provides the related listing.

18 Schaffer 1956, 115-116.Götze 1933, 22-23, 32-33.

19 Steiner 1957, 549.

20 Van den Hout 1995a, 554

21 Macqueen 1986, 50, Fig. 26.

22 Boehmer 1972-75, 431ff.
}

are depicted as the figure in relief number 34 at Yazllkaya ${ }^{23}$.

Until recent times there was no knowledge of any document from Anatolia relating to king cult deified while in life as it was in Mesopotamia. Whereas in Mesopotamia the kings have used god name or god determinative since Akkadian Period $^{24}$. In the Victory Stele of Naram-Sin, the King of Agade, the king is depicted as a god with the horned hat ${ }^{25}$. Hittite kings did not use any god determinative, but they have used the title of "DDTU ${ }^{S I, 26}$.

The saying "Have him, offer me drink (pour libation to me), my sun, the great king labarna Tudkhaliya, at virgin place ..." in the Emirgazi inscriptions ${ }^{27}$ is an evidence of the fact that the Hittite kings in life have transformed themselves into cult objects.

This document points out the fact that an image of Tudkhaliya IV, deifed while in life, may be somewhere. Akurgal ${ }^{28}$ is in the opinion that Tudkhaliya IV was deified while in life, and that his missing deified statue $e^{29}$ was on the unoccupied base in Room B at Yaz1likaya. According to $\mathrm{Bittel}^{30}$ the subject statue should belong to some earlier king since there is no specific information. Shuppiluliuma II reports that he erected and "placated" an image of Tudkhaliya in $\mathrm{E}^{\mathrm{NA4}}{ }^{\mathrm{h}} \mathrm{ekur}^{31}$. As to Kohlmeyer, he states that the missing

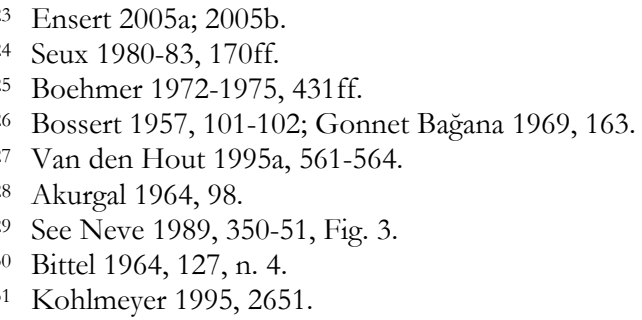


statue in Room B of Yazllikaya is the statue of Tudkhaliya IV deified after death $^{32}$. As of this date neither the iconographic features ${ }^{33}$ of the missing statue are known nor it is certain that there was such a statue there at some time.

Presently there are two images of Tudkhaliya IV that are confirmed by inscriptions: Tudkhaliya IV is depicted in the king iconography ${ }^{34}$ with the cap, the long mantel and the lituus in reliefs $64^{35}$ and $81^{36}$ at Yaz1likaya. Tudkhaliya IV Relief, number 64 which is the largest image in Room A of Yazılıkaya with a height of 2.63 meters, should be aimed to impress the people visiting the cella. Here, in room A, Tudkhaliya IV is identified as deified after death ${ }^{37}$. Although the statement of Khattushili III, reading "When my grandfather Shuppiluliuma arrived at the mountain" indicates that the new dwelling of a dead king is on a mountain, it should also be considered that the mountains are a part of the Sun God iconogaphy. The posture of Tudkhaliya IV on two mountain-like elevations, is in agreement with the "DUTU ${ }^{S t \text { " }}$ title of the Hittite kings. As in the case with the royal seals, the identity inscription of Tudkhaliya IV is crowned by the winged sun disk and the labarna (hero) signs appear among his titles. Therefore Tudkhaliya IV should have been depicted

\footnotetext{
32 Kohlmeyer 1995, 2651.

33 Neve (1989, 351, Fig. 3) formed a mental picture of the statue and drew it.

34 The mortal, deified while in life, was not allowed to have himself depicted with the horned hat and in god dress (Boehmer 1972-75, 431-432).

35 Bittel et al. 1975, 155-157, Taf. 60.

36 Bittel et al. 1975, Taf. 62.

37 Bossert 1957, 97-98; Akurgal 1995, Șek. 45.

38 Haas 1994, 216.
}

here as a king in power $^{39}$ with the title "DDTU ${ }^{S I}$ ".

Van den Hout explains the depictions of Tudkhaliya IV as follows ${ }^{40}$ : In relief 64 with the Sun God dressing he is the supreme judge and in the seal impression from Ugarit with the Storm God dressing he is the supreme warrior. There is no symbol or inscription regarding as to who is the subject small god figure from Ugarit except the fact that he is in the Hittite god dressing. As also many scholars do, Van den Hout ${ }^{41}$ agrees that the Hittite kings were depicted with horny hats only when they were deified after death.

A depiction of Tudkhaliya (?), dressed as the Hittite gods, is on the stele of House (chapel)-a, at Boğazköy ${ }^{42}$. The king wears a pointed hat with five pairs of horn, a short skirt and a pair of shoes with the upturned toes and holds a lance resting on the right shoulder (Fig. 3). The hieroglyphic inscription above the left hand of the figure shows that he is "Great King Tudkhaliya" ${ }^{43}$. The inscription neither includes the winged sun disk nor the labarna (hero) title. It is considered that the figure is Tudkhaliya $\mathrm{I}^{44}$, or Tudkhaliya

\footnotetext{
39 Neve $(1992,85)$, is in the opinion that the Hittite kings are not deifed only after death but also while in life.

40 Van den Hout 1995a, 561.

41 Van den Hout 1995a, 559.

42 Neve 1986, 395-397, Abb. 29-30; Neve 1987, 63, Abb. 16-18; Neve 1992, 34-36, Abb. 100-104.

43 Neve 1992, 35.

44 Neve 1987, 67-68; Neve 1992, 36; Gonnet 1987, 69 ff.
} 
$\mathrm{III}^{45}$, the ancestors of Tudkhaliya IV, or Tudkhaliya $\mathrm{IV}^{46}$ in life.

The written documents mention of the death of the Hittite kings as "he became god". "DINGIR LIM -iš kiš" means "to become god" "47. Ünal explains that some texts record that the soul is of god origin and that the statement of "to become god" is the deification of the soul ${ }^{48}$. Starting with the funeral ceremonies, sacrifices of the drinking and eating kind were offered to the souls of the dead kings (akkantaš ZI ${ }^{49}$. The cult of kings deified after death were also covered under the hierarchy of the gods ${ }^{50}$. Some important religious texts related with the ancestral cult and the kingship record some of the offerings for dead kings and partly for their wifes and other family members ${ }^{51}$. The cult related with the dead members of the royal family has turned each of them into a $\operatorname{god}^{52}$. Sacrifice offerings to dead kings, deified after death, equivalent with those offered to other gods, continued for centuries $^{53}$. Thus it is understood that the deified kings were respected and also worshipped as the other gods. Some houses, tributes, settlements and stone houses were assigned to the dead kings as some kind of a foundation ${ }^{54}$. Three kings of the Hittite Empire Period, namely

\footnotetext{
45 Darga 1992, 194-195. Also Lumsden (1990) thinks that the figure is one of the ancestors of Tudkhaliya $\mathrm{IV}$, bearing the same name as his.

46 Hawkins 1990, 311-312, n. 48; Van den Hout 1995a, 557; Savaş 2002, 120-121.

47 Ünal 1975-76, 168.

48 Ünal 1975-76, 168.

49 Ünal 1975-76, 168; Van den Hout 1995a, 545-546.

50 Ünal 1975-76, 168.

51 Haas - Wäfler 1977, 106ff .

52 Van den Hout 1995a, 546.

53 Otten 1969, Table II - III.

54 Ünal 1975-76, 169.
}

Tudkhaliya, Arnuwanda and Shuppiluliuma, have "stone houses"55. Imparati", who rescrutinized the related texts, evaluates the presence of the phrase of "E. $\mathrm{Na}_{4}$ DINGIR ${ }^{\text {LIM" }}$ (the stone house of the gods) before the name of Tudkhaliya IV, as an evidence that he was not yet a god, that is he was not dead when this king had the stone house constructed.

It is known that the seals with the god and/or goddess depictions protect the bearers. The written documents narrate that the ancestral gods also protect the king as the divinities of the father (of the king) and, the divinities of the father and the mother $\mathrm{do}^{57}$. This explains reason why the deified kings after death are depicted on the seals together with the other divinities.

A similar one of subject small god figure is also in a seal impression of Tudkhaliya IV with the embracement scene from Boğazköy ${ }^{58}$.

In the seal impression of Murshili III / Urkhi-Teshub from Boğazköy ${ }^{59}$ a winged sun disk crowns the whole composition. The identity of the owner of the seal is written both at the top right of the seal and at the middle bottom of the seal ${ }^{60}$. The king's identity inscription at the bottom is crowned by a second winged sun disk. The storm god in his cart with the double bulls is in the middle of the seal impression. Behind the storm god is a small god figure without any identity in-

\footnotetext{
55 Otten 1958, 107.

6 Imparati 1977, 59, 61, n. 160.

7 Haas 1994, 193.

5 Neve 1992, 315, Abb. 7d.

59 Neve 1991, Abb. 29c.

60 Van den Hout 1995a, 555.
} 
scription. The small god figure holds a lance with the left hand and a bow with the right hand. The bow is hanging down from the shoulder. The small god figure is thought to be representing Murshili III /Urkhi-Teshub ${ }^{61}$. But there is nothing indicating that the identity inscriptions of Murshili III, the owner of the seal, may belong to the subject small figure. Furthermore the image of the Storm God is between the subject small figure and the identity inscriptions. Van den Hout, considering that the subject god figure represented Murshili III, the owner of the seal, he concluded that the Hittite kings were deified while in life starting with Murshili III $^{62}$. Since there is no identity incription of the subject figure, it is not definite as to whom is represented by this figure. Since the bow and the lance conform with the iconography of deified kings after death, the figure may be representing any of the ancestor kings of Murshili III but presently it does not seem possible to say which king it is.

According to Laroche the god figure, depicted with the horny hat on the demon, in the impression of the cylinder seal from Ugarit (RS 17.59) is Ini-Tešub, the king of Karkamish ${ }^{63}$. But Schaeffer states that the figure is a second god, protecting the king $^{64}$. The figure differs from the figures in this article because he carries the mace on the shoulder and he is standing on a demon.

There is a deified king figure in the relief (Fig. 2) at the left of the entrance of

\footnotetext{
61 Van den Hout 1995a, 555.

62 Van den Hout 1995a, 559

63 Schaeffer 1956, 23-26, Fig. 22-23.

64 Schaeffer 1956, 25.
}

Room 2 in the Southern Fortress at Boğazköy ${ }^{65}$. From the hieroglyphic inscription on this relief it is understood that said figure belongs to "Shuppiluliuma, the Great King" "66. The inscription on the right wall of the room indicates that the room was constructed at the time of King Shuppiluliuma II. The king, wearing the pointed hat with three horns, holds a bow on the left shoulder and a lance on the ground with his right hand ${ }^{67}$. The figure depicts King Shuppiluliuma II and the relief is associated with the cult of death ${ }^{68}$. Hawkins states that the figure may be considered as being Shuppiluliuma I, acting as if he is the protecting god of the monument. However it is understood that he also agrees with Otten in that the figure may represent Shuppiluliuma $\mathrm{II}^{69}$. He indicates that although the figure is depicted in the iconography of a warrior god, it is not certain that it is intended to be understood as being deified. Although Güterbock ${ }^{70}$ also thought that the king could had been dead he pointed out that there were other king depictions of divine nature as it is in the depiction of Khattushili III at Frraktin. The last sentence of the hieroglyphic inscription in the right wall while entering the room reads "Here a Divine Earth-Road in that

\footnotetext{
65 Neve 1990, 279-286; Neve 1992, 69-80, Abb. 204ab, 213-4; Hawkins 1990, 305-314; Van den Hout 1995a, 558.

66 Neve 1992, 72; Kohlmeyer 1995, 2648.

67 Neve 1992, 71.

68 Neve 1989-90, 13-14; Neve 1992, 71, 80; Woudhuizen (1996, 195), Savaş (2002, 120-121) and Kohlmeyer are in the opinion that he was Shuppiluliuma II; Kohlmeyer (1995, 2648), states that the figure of the warrior on the King Gate is a king, deified after death.

69 Hawkins 1995,19-20.

70 Güterbock 1993, 226.
} 
year (I) construct(ed)" "71. Considering the size of the chamber ${ }^{72}$ it might be a tomb, which had been caused to be constructed by king Shuppiluliuma for himself before he $\operatorname{died}^{73}$. Also the subject deified image of the king is in a nature supporting this idea $^{74}$.

Khattushili III pours libation to the Storm $\operatorname{God}^{75}$ in the left scene (Fig. 6) of Firaktin Rock Monument ${ }^{76}$. The king wears a pointed hat with one horn and a dress similar as that of the Storm God. He girds a sword with the crescent handle and with his left hand he holds the bow which is on his left shoulder. Queen Pudukhepa pours libation to Goddess Khepat in the right scene (Fig.8) Queen and the goddess are depicted with similar dresses.

71 Hawkins 1995: translation; Hawkins (1990, 314) considers that the room might have been designed as an artificial entrance to the underworld. Alp (2001, 170) also reads it similarly. However Woudhuizen $(1996,202)$ reads it as "(and I) did the (same) in this offering pit (every) year.

72 The chamber is $4 \mathrm{~m}$ long, $2 \mathrm{~m}$ wide at the front and $1.6 \mathrm{~m}$ at the back. It is $3.3 \mathrm{~m}$ high at the front and $3.1 \mathrm{~m}$ at the back (Neve 1992, 70).

73 Neve (1989-90, 13-14 ) qualified Chamber 2 first as a tomb chamber based on its inscription. Afterwards he reconsidered Chamber 2 together with the pool and the channel, and based on the votive pots from the pool he appraised that Chamber 2 should have served for some cultic purpose but probably not as a tomb chamber (Neve 1991, 343-344).

74 Darga $(1989,197)$ has been doubtful whether Shuppiluliuma I had a deified image or not. Also she defines the figure, in the king dress and crowened by the winged sun disk on the back wall, as the depiction of Shuppiluliuma II, deified after death.

75 Meriggi $(1975,309 \mathrm{f}$.) states that the name of the god is in Luwian.

76 For more detailed information of Firaktin Rock Monument see Börker Klähn 1982, 260-262; Kohlmeyer 1983, 67-74.
The depictions of King Khattushili III and Queen Pudukhepa in similar dressings as those of the divinities that they pour libations to are explained as follows: They wanted to make themselves identical with the divinities ${ }^{77}$. Relieves are their depictions of propaganda ${ }^{78}$; it is the demonstration of the power of the divine king $^{79}$; the king is depicted as the priest and he tried to look like his gods ${ }^{80}$; limitations are brought to his priesthood mission by being depicted in his warrior dress; in his confrontation with the god he wore this dress ${ }^{81}$.

The relief is dated to the time of reign of Khattushili III ${ }^{82}$ or to sometime later after death of Khattushili III ${ }^{83}$. Akurgal states that according to the written documents only the kings, deified after death, are depicted with the horn ${ }^{84}$, however he is in the opinion that, here, Khattushili III is in life. Alexander ${ }^{85}$ thought that the figure here could be Khattushili III in life and that the Storm God of Nerik would pass over the lituus, resting on his shoulder, to the king. However, such an idea may only be an assumption because there is not any scene on the monument related with this viewpoint. Due to the reason that the lituus is a

\footnotetext{
77 Van den Hout 1995a, 559.

78 Kohlmeyer 1983, 74.

79 Alexander 1998, 18.

80 Bittel et al. 1967, 108.

81 Kohlmeyer 1983, 73.

82 Laroche 1989, 301-302;. Bittel 1939, 567, Bittel 1984 11-12, n. 8; Bittel 1989, 35; Börker Klähn 1984, 45, n. 48; Akurgal 1962, 112; Van den Hout 1995b, 1112-1113.

83 Hawkins 1990, 311 n. 48; Hawkins 1995, 19; Mayer Opificius 1989, 361-363; Savaş 2001, 107 n. 88, 108 n. 90; Savaş 2002, 120-121.

84 Akurgal 1962,112; Akurgal 1964, 108.

85 Alexander 1998, 18.
} 
kingdom mace, he elucidated the scene as the authorization of the king to rule. However, he has not considered that the lituuses are divinity symbols when they are carried with the curved ends upwards, as it is also seen here ${ }^{86}$. Thus, he compared this scene to the scene of the Investiture of Zimri-lim on the fresco at the Mari Palace ${ }^{87}$ and elucidated the scene as the legitimation of the kingship of Khattushili III $^{88}$. And as to the depiction of the king in the god iconography, he explained it as the display of the divinity power of the king ${ }^{89}$.

The royal couple were vested with charismatic powers surpassing the power of the people ${ }^{90}$. The enthronement rituals were to empower the Hittite kings with the required divine spirits ${ }^{91}$. The legalization process was realized by the supreme gods of the country during the great New Year Ceremonies when all the gods convened at the Weather God's home ${ }^{92}$.

The house of the Weather God, mentioned in the written documents, should be Yazilikaya as also pointed out by Haas $^{93}$. Here, the Weather God and his family ${ }^{94}$ are depicted together with the other gods. The Firaktin rock monument

\footnotetext{
86 Based on texts, Alp $(1948,309-310)$ indicated that although there is no record that GISkalmus was carried by the gods, there is mention about the GISPA's of the gods. But he left the question unanswered as to whether the maces (walking sticks) with the curved ends, mentioned in the texts, were the GISPA's or not.

87 Alexander 1998, 18.

88 Alexander 1998, 18

89 Alexander 1998, 18.

90 Haas 1994, 194

91 Haas 1994, 191.

92 Haas 1994, 192.

93 Haas 1994, 639.

94 Bittel et al 1975, Pl 58.
}

can not be depicting the legalization process because it does not conform with the preceding description. Since Khattushili III is depicted as a god here, he should not had been in life but dead and deified.

The hieroglyphic inscription in the left side of the monument first was read as "daughter of the land of Kizzuwatna, beloved (by) the $\operatorname{god}(\mathrm{s})$ "'95 but later it was read as "daughter of Kizzuwatna, having become god" ". Therefore the monument may be the death memorial of Queen Pudukhepa $^{97}$. In addition the fact that Queen Pudukhepa had worn a similar hat as that of Goddess Khepat may indicate that she was deified after death ${ }^{98}$. This hat is worn by both the goddesses and the queens. The hat in profile is a hieroglyhic sign that means "queen" of Queen Pudukhepa as deified after death in this relief is in support of the viewpoint that King Khattushili III was also depicted here as deified after death. As to the dead king and queen pouring libation, this may be explain by the sacrifice-mantalliya. According to the explanation of Ünal, a person may have himself or one of his ancestors forgiven of a sin, commited, by offering a sacrifice of mantalliya and the dead may also appear as one sacrificing to ridden of his pangs of conscience $^{100}$. It is considered that some symbols or figurines represent the dead during the sacrificing ${ }^{101}$. Unnal states that

\footnotetext{
5 Kohlmeyer 1983, 72; Hawkins 2000, 39 n. 12.

6 Woudhuizen 1996, 191-194.

7 Woudhuizen 1996, 193; Savaş 2001, 100-101.

8 Mayer Opificius 1989, 362.

Laroche 1960, Lar. 15-16.

100 Ünal 1975-76, 172.

101 Ünal 1975-76, 173.
} 
this tradition was adapted from Kizzuwatna by the influence of Queen Pudukhepa ${ }^{102}$. This tradition, which was started by queen Pudukhepa, might have been applied in Firaktin by herself in person.

Based on the deification of King Khattushili III and Queen Pudukhepa it may be thought that the Firaktin reliefs might have been carved for the royal couple ${ }^{103}$ .On the horizontal rock platform above the relief at least two man made holes, called the cup-marks ${ }^{104}$ are thought to have been used for cremation burials ${ }^{105}$.

Tarkasnawada, the king of Mira (Fig. 4), is depicted in the Karabel A Rock Monument $^{106}$. The king wears a short skirt and the one-horned pointed hat. $\mathrm{He}$ holds a bow, resting on his right shoulder with one hand and a lance, resting on the ground, with the other hand. He girds a sword with the crescent handle. There is also a similar figure in Karabel $\mathrm{B}^{107}$. Due to the reason that the image of King Tarkasnawada, iconographically, resembles that of King Khattushili III in the Firaktin Rock Monument it is considered that also King Tarkasnawada was depicted while he was in life ${ }^{108}$. There is a male figure on the 'Tarkondemos' silver seal $(57.1512)^{109}$, which is said to have come from İzmir. The male figure, which should represent Tarkasnawada, the king

\footnotetext{
102 Ünal 1975-76, 173.

${ }^{103}$ Kohlmeyer $(1983,74)$ is in the opinion that it may also be a place used for cultic purposes by reason of its location and the hollows on the terrace.

104 Stokkel 2005, 172; Ussishkin 1975, 86.

105 Savaş 2001, 99 n. 35, 103.

106 For more information, see Kohlmeyer 1983, 12-28; Hawkins 1998.

107 Börker Klähn 1982, 256; Hawkins 1998, 8.

108 Kohlmeyer 1983, 25.

109 Güterbock 1977, 11-16, Fig. 4; Hawkins 1998, 2.
}

of Mira, wears a cap and a long mantel and holds a lance (or a long stick?) in his right hand. The depiction of King Tarkasnawada on the 'Tarkondemos' seal should be that of the time he was in life and the one in the Karabel A Rock Monument should be that as deified after death. Hollows and troughs for the offerings ${ }^{110}$ show that the monument is a cult place.

Kurunta, the King of Tarkhuntassha is depicted as a god with a short skirt and a pointed hat that has three horns in the Hatip Rock Monument at Konya (Fig. 7) ${ }^{111}$. He girds a sword. He holds a lance (?), resting on the ground with his left hand and holds a bow resting on the right shoulder with the right hand. The hieroglyphic inscription at the back of the king reads "Kurunta, the great king, [the hero], son of $[\mathrm{Mu}]$ watalli, the Great King, the hero" "112. Due to the reason that Kurunta did not have a successor, who would build a monument in his memory, the above depiction is thought to be Kurunta while in life ${ }^{113}$. The text that describes the $\mathrm{Na}_{4}$ hekur of Kurunta states that the monument was built on a rock, steep on all sides except one where a access road was built ${ }^{114}$.

Prince Kuwalanamuwa ${ }^{115}$ is depicted in a similar iconography in the HanyeriGezbel Rock Monument ${ }^{116}$. The figure,

\footnotetext{
110 Börker Klähn 1982, 256.

111 Bahar 1996, 2-5; Dinçol 1998, Fig. 1.

112 Dinçol 1998, 161.

113 age. 162-163.

114 Houwink ten Cate 1966, 181-182, Stokkel 2005, 179.

115 See Börker Klähn 1982, 258-259, Taf. 314b;

Kohlmeyer 1983, 86-90, Fig. 36.

116 Ünal 2002, 149; Kohlmeyer 1983, 88-90.
} 
which girds a sword, holds a lance, resting on the ground with his right hand and a bow, resting on his left shoulder with his left hand (Fig. 5). In the publications the hat of the figure is drawn either with one horn ${ }^{117}$ or no horn ${ }^{118}$. By his identification inscribed on the Imamkulu Rock Monument ${ }^{119}$ it is understood that Prince Kuwalanamuwa is also depicted there ${ }^{120}$. The figure resembles the prince on the Hanyeri-Gezbel Rock Monument but it can not be determined whether his hat is with the horn or not.

Consequently, the above images show that the Hittites had a systemized king iconography of kings deified after death. Also, logically, a king in power and a king deified after death should not have been depicted with the same iconographic features. They have shown this difference in their art.

The iconographic common features of Hittite kings, deified after death, may be outlined as follows:

According to their hieroglyphic inscriptions it is definite that all of them are either princes or kings ${ }^{121}$.They wear the horned hats, the short skirts and the shoes with the upturned toes. They gird

117 Börker Klähn (1982, 258, Taf. 314b) states that the hat is with a horn; The horn is visible in the photographs of Akurgal 1995, Şek. 63b.lev. 60b, 61a.

118 Kohlmeyer 1983, Fig. 36.

119 Börker Klähn 1982, 259, Taf. 315; Ünal 2002, 149, Res. 45.

120 Hawkins 2000,39 n. 14.

${ }^{121}$ It is hard to say whether the two god figures, facing the sitting goddess at Gavurkalesi, are king or prince depictions because they don't bare the identity inscriptions. See Börker Klähn 1982, 258, for detailed information related with Gavurkalesi. swords ${ }^{122}$, and hold lances ${ }^{123}$. and/or bows ${ }^{124}$. Their hieroglyphic inscriptions of identity are not crowned by the winged sun disk ${ }^{125}$, and they do not bear the god and the tabarna (hero) ${ }^{126}$ signs.

Under the consideration of the above, it may be construed that the subject small god figure in the seal impression is an ancestor of Tudkhaliya IV and most probably his grandfather Murshili II, deified after death.

Assist. Prof. H. Kübra Ensert

Mustafa Kemal Üniversitesi

Fen-Edebiyat Fakültesi

Arkeoloji Bölümü

Tayfur Sökmen Kampüsü

Antakya-HATAY

e-mail: hkensert@mku.edu.tr

122 Sword is a weapon used by the Hittite gods as done by the Hittite kings. For example the gods, number 40-42 and 44 at Yazllikaya, gird similar swords as those done by the Hittite kings (Bittel et al 1967, 114).

123 Depiction of the figure with the bow and the lance is considered as a sign that the figure may be of a prince, a king or even a great king (Kohlmeyer 1983, 94; Alexander 1998, 16).

${ }^{124}$ In a like manner the bow, also, is known as a weapon of the Hittite gods (Bittel et al 1967, 116). But if the deceased would be a king a text from a royal family regarding his burial by cremation would read "a bow and arrows are placed in his hand"(Kaasian ve diğ. 2002, 24).

125 The winged sun disk does not crown the identity inscriptions of dead kings in the hieroglyhic inscriptions as may be seen with the Nişantaşı at Boğazköy (Bossert 1957, 107), Yalburt-Ilgın at Konya and the stele of Tudkhaliya IV from Boğazköy (Alp 2001, 161, 171), and others. The lack of the winged sun disk in the hieroglyphic inscription (Hawkins 1995), narrating the deeds of Shuppiluliuma II in Chamber 2 in the Southern Fortress at Boğazköy may result from the fact that it might have been constructred to be used after death of the king.

126 According to Kohlmeyer $(1995,2648)$ these titles are not used in the stele of Tudkhaliya in Temple 5 and in the relief of Khattushili III in the Firaktin Rock Monument. 


\section{List of Figures}

\section{Figure 1a.}

The seal impression of Tudkhaliya IV (after Alp 1998, Şek. 1).

\section{Figure 1b.}

The small god figure in Figure 1a

\section{Figure 2.}

The relief of the Great King Shuppiluliuma II in the Room 2 at Boğazköy (after Van den Hout 1995a Abb. 3).

\section{Figure 3.}

The relief of Tudkhaliya (?) in House (chapel)-a at Boğazköy (after Neve 1987, Abb. 17)

\section{Figure 4.}

The Relief of Tarkasnawada, the king of Mira in the Karabel A Rock Monument (after Hawkins 1998, Fig. 4a).

\section{Figure 5.}

The relief of Prince Kuwalanamuwa in the Hanyeri-Gezbel Rock Monument (after Börker Klähn 1982, 314b)

\section{Figure 6.}

The relief of Khattushili III in Firaktin Rock Monument (after Kohlmeyer 1983, Fig. 24)

\section{Figure 7.}

The relief of Kurunta, the King of Tarkhuntassha in the Hatip Rock Monument at Konya. (after Dinçol 1998, Fig. 1).

\section{Figure 8 .}

The relief of Queen Pudukhepa in Firaktin Rock Monument (after Kohlmeyer 1983, Fig. 25). 


\title{
KAYNAKÇA / BIBLIOGRAPHY
}

\author{
Akurgal 1995 \\ E. Akurgal, Hatti ve Hitit Uygarliklar (1995) \\ Akurgal 1962 \\ E. Akurgal, The Art of Hittites (1962) \\ Akurgal 1964 \\ E. Akurgal, "Die Kunst der Hethiter", in: G. Walser (ed.), Neuere \\ Hethiterforschung (1964) 74-118
}

Alexander 1998

R. L. Alexander, "Contributions to the interpretation of the Fraktin Reliefs", in: S. Alp - A. Süel (eds.), III. Uluslararasi Hititoloji Kongresi Bildirileri, Corum 16-22 Eylül 1996/Acts of the III In International Congress of Hittitology Corum, September 16-22, 1996 (1998) 15-20

Alp 2001

S. Alp, Hitit Çăğnda Anadolu, Civiyaz̨l ve Hiyeroglif Yaz̨l Kaynaklar (2001)

Alp 1998

S. Alp, “IV. Tuthaliya'nın tahta çıkmadan önceki diğer adı”, in: S. Alp - A. Süel (eds.), III. Uluslararası Hititoloji Kongresi Bildirileri, Corum 16-22 Eylül 1996/ Acts of the III In International Congress of Hittitology Corum, September 16-22, 1996 (1998) 21-26

Alp 1948

S. Alp, "Hitit Metinlerinde Gişkalmuş 'LITUUS' VE HUB.BI 'KÜPE", Belleten XII, 46, 1948, 301-319

Bahar 1996

H. Bahar, "Konya-Hatip'te bulunan yeni bir Hitit anıtı", Arkeoloji ve Sanat, 18, 1996, 73, 2-5

Beran 1967

T. Beran, Die Hethitische Glyptik von Boğazköy (1967)

Bittel 1989

K. Bittel, "Bemerkungen zum hethitischen Yazıllkaya", in: K. Emre - B. Hrouda - M. Mellink - N. Özgüç (eds.), Tahsin Özgüç'e Armă̆an, Anatolia and the Ancient Near East Studies in Honor of Tahsin Özgüç (1989) 33-38

Bittel 1984

K. Bittel, Denkmäler eines hethitischen Großkönigs des 13. Jahrhunderts vor Christus (1984)

Bittel 1964

K. Bittel, "Einige Kapitel zur Hethitischen Archaologie", in: G. Walser (ed.) , Neuere Hethiterforschung (1964) 119-144

Bittel 1939

K. Bittel, "Beobachtungen in Kappadokien”, A A 54, 1939, 548-568

Bittel ve diğ. 1975

K. Bittel - J. Boessneck - B. Damm - H. G. Güterbock - H. Hauptmann - R. Naumann - W. Schirmer, Das Hethitische Felsheiligtum Yazllıaya (1975)

Bittel ve diğ. 1967 K. Bittel - R. Naumann - H. Otto: Yazllıkaya Architektur, Felsbilder Inschriften und Kleinfunde (1967)

Boehmer 1972-75 R. M. Boehmer, "Hörnerkrone", Reallexikon der Assyriologie 4 (1972-75) 431-434

Bossert 1957

H. Th. Bossert, "Meine Sonne”, Orientalia 26, 1957, 97-126

Börker Klähn 1984 J. Börker Klähn, “Zur Lesung der Fraktin-Beischrift”, OrAnt 19, 1984, 3748 
Börker Klähn 1982 J. Börker Klähn, Altvorderasiatische Bildstelen und Vergleichbare Felsreliefs (1982) Börker Klähn - J. Börker Klähn - C. Börker Klähn, "Eflatun Pınar, zur Rekonstruktion, Börker 1976 Deutung und Datierung", JdI 90, 1976, 1-41

Dinçol 1998 A. Dinçol, "The Rock Monument of the Great King Kurunta and its Hieroglyphic Inscription", in: S. Alp - A. Süel (eds.), III. Uluslararast Hititoloji Kongresi Bildirileri, Corum 16-22 Eylïl 1996/Acts of the IIIrd International Congress of Hittitology Corum, September 16-22, 1996 (1998) 159166

Ensert 2005a $\quad$ H. K. Ensert: “M.Ö. İkinci Binde 'Kanatlı Güneş Kursu' ile taçlandırılmış Anadolulu Hitit Figürleri", Anatolia / Anadolu 28, 2005, 25-47

Ensert 2005b H. K. Ensert, "Is 'the Figure No. 34 at Yazllikaya' the Sungod or a king", in: A. Süel (ed.), V. Uluslararasi Hititoloji Kongresi Bildirileri, Çorum 02-08 Eylül 2002/Acts of the Vth International Congress of Hittitology Corum, September 02-08, 2002 (2005) 293-302

Gonnet 1990 H. Gonnet, “II. Muwatalli'nin mühürleri üzerinde gözlemler”, Belleten 54, 1990, 9-15

Gonnet 1987 H. Gonnet, "Note Additionelle. Boğazköy-Hattuša, Ergebnisse der Ausgrabungen in der Oberstadt", Anatolica 14, 1987, 69-71

Gonnet-Bağana 1969

H. Gonnet-Bağana, "Arkeolojik belgelere göre Eti Güneş Kursları", Anadolu / Anatolia 11, 1967, 161-166

Götze 1933

A. Götze, "Die Annalen des Mursilis", $M V A e G$ 38/4 (1933)

Güterbock 1993

H. G. Güterbock, "Sungod or King?”, in: M J. Mellink - E. Porada - T. Özgüç (eds), Nimet Özgüç'e Armağan, Aspects of Art and Iconography: Anatolia and its Neighbours Studies in Honor of Nimet Özgüc (1993) 225-226

Güterbock 1977 H. G. Güterbock, "The Hittite Seals in the Walters Art Gallery", The Journal of The Walters Art Gallery, Essays in Honor of Dorotby Kent Hill, 36, 1977, 7-16

Haas 1994

V. Haas, Geschichte der Hetbitischen Religion (1994)

Haas - Wäfler 1977 V. Haas - M. Wäfler, "Bemerkungen zu Ehheštī/ā". Ugarit-Forschungen 9, 1977, 87-122

Hawkins 2000

J. D. Hawkins, Corpus of Hieroglyphic Inscriptions. Part 1 (2000)

Hawkins 1998

J. D. Hawkins, “Tarkasnawa King of Mira: 'Tarkondemos', Boğazköy sealings and Karabel", AnSt 48, 1998, 1-31

Hawkins 1995 J. D. Hawkins, The Hieroglyphic Inscription of the Sacred Pool Complex at Hattusa (SÜDBURG) (1995)

Hawkins 1990 J. D. Hawkins "The new inscription from the Südburg of BoğazköyHattuša”, AA 1990, 305-314

Houwink ten Cate Ph. H. J. Houwink ten Cate, "Mursilis' Nortwestern Campaigns, 1966 Additional Fragments of His Comprehensive Annals", JNES 25, 1966, 162-191 
Imparati 1977

Kassian ve diğ.

2002

Kohlmeyer 1995

Kohlmeyer 1983

Laroche 1989

Laroche 1960

Lumsden 1990

Macqueen 1986

Mayer-Opificius 1989

Meriggi 1975

Neve 1992

Neve 1991

Neve 1990

Neve 1989-90

Neve 1989

Neve 1987

Neve 1986

Otten 1969

Otten 1958
F. Imparati, "La Istituzioni Cultuali del na4 hekur e il Potere Centrale Ittita”, SMEA 18, 1977, 19-64

A. Kassian - A. Korolëv - A. Sidel, Hittite Funerary Ritual šalliš wataiš, Alter Orient und Altes Testament, Band 288 (2002)

K. Kohlmeyer, "Anatolian Architectural Decorations, Statuary, and Stelae", in: J. M. Sasson (ed.), Civilizations of the Ancient Near East. III, (1995) 2639-60

K. Kohlmeyer, "Felsbilder der hethitischen Großreichszeit", ActaPraehisA 15, 1983, 7-154

E. Laroche, "Les reliefs de Fraktin", in: K. Emre - B. Hrouda - M. Mellink -N. Özgüç (eds.), Tahsin Özgüç'e Armağan, Anatolia and the Ancient Near East Studies in Honor of Tahsin Özgüç (1989) 301-302

E. Laroche, Les Hiéroglyphes Hittites (1960)

S.P. Lumsden, Symbols of Power: Hittite royal iconography in seals (1990)

J. G. Macqueen, The Hittites and their contemporaries in Asia Minor (1986)

R. Mayer-Opificius, "Hethitische Kunstdenkmäler des 13. Jahrhunderts v. Chr”, in: K. Emre - B. Hrouda - M. Mellink -N. Özgüç (eds.), Tahsin Özgüç'e Armağan, Anatolia and the Ancient Near East, Studies in Honor of Tahsin Özgüc (1989) 357-63

P. Meriggi, Manuale di Eteo Geroglifico. II Testi-Tavole, 2a e 3a Serie (1975)

P. Neve, "Hattuşa - Stadt der Götter und Tempel”, $A W(1991)$

P. Neve, "Die Ausgrabungen in Boğazköy- Hattuša 1990”, A A 1991, 299348

P. Neve, "Die Ausgrabungen in Boğazköy- Hattuša 1989", A A 1990, 267303

P. Neve, "Boğazköy-Hattusha, New results of the excavations in the upper city", Anatolica 16, 1989-90, 7-19

P. Neve, "Einige Bemerkungen zu der Kamer B in Yazılıkaya", in: K. Emre - B. Hrouda - M. Mellink -N. Özgüç (eds.), Tahsin Özgüç'e Armağan, Anatolia and the Ancient Near East, Studies in Honor of Tabsin Özgüc (1989) 345-355

P. Neve, "Boğazköy-Hattuša, Ergebnisse der Ausgrabungen in der Oberstadt”, Anatolica 14, 1987, 41-88

P. Neve, "Die Ausgrabungen in Boğazköy- Hattuša 1985", A A 1986, 367406

H. Otten, "Hitit tarihinin Kaynakları ve Eski Doğu kronolojisi”, (transl. H. Ertem) Belleten 33, 1969, 129-132, 359-369

H. Otten, Hethitische Totenrituale (1958) 
Savaş 2001

Savaş 2002

Schaeffer 1956

Seux 1980-83

Steiner 1957

Stokkel 2005

Ussishkin 1975

Ünal 2002

Ünal 1975-76

Van den Hout $1995 \mathrm{a}$

Van den Hout 1995b

Woudhuizen 1996
S. Ö. Savaş, “Kizzuuatnalı Büyük Hitit Kraliçesi Puduhepa'nın Evlilik Anıtı ile Ölüm Anıtı”, in: É. Jean - A. M. Dinçol - S. Durugönül (eds.), La Cilicie: Espaces et Pouvoirs Locaux (2e millénaire av. J. C. $-4^{e}$ siècle ap. J. C.), Actes de la table Ronde Internationale D'Istanbul, 2-5 novembre 1999/ Kilikya: Mekânlar ve Yerel Gücler (M. Ö. 2. binyıl-M. S. 4. yüzyll). Uluslararası Yuvarlak Masa Toplantısı Bildirileri Istanbul, 2-5 Kasım 1999 (2001) 95-114

S. Ö. Savaş, “Hititler'de 'Fırtına Tanrısı' ile 'Boğa Kültü’ üzerine bazı gözlemler ve yorumlar", Archivum Anatolicum / Anadolu Arşivleri 5, 2002, 97 170

C. F.-A. Schaeffer, "Sceaux et Cylindres Hittites, Épée Gravée du Cartuche de Mineptah, Tablettes Chypro-Minoennes et Autres Découvertes Nouvelles de Ras Shamra”, Ugaritica 3, 1956

M. J. Seux, “Königtum”, Reallexikon der Assyriologie 6 (1980-83) 140-173

G. Steiner, "Gott”, Reallexikon der Assyriologie 3 (1957) 532-575

P. J. A. Stokkel, "A new perspective on Hittite rock Reliefs", Anatolica 31 2005, 171-187

D. Ussishkin, "Hollows Cup-Marks, and Hittite Stone Monuments", AnSt 25, 1975, 85-103

A. Ünal, Hititler Devrinde Anadolu I (2002)

A. Ünal, "Hititlerde ölülere sunulan kurban hakkında bazı düşünceler", Anadolu/Anatolia 19, 1975-76, 165-174

Th. P. J. van den Hout, "Tuthaliya IV. und die Ikonographie hethitischer Großkönige des 13. Jhs.”, BiOr 52, 1995, 545-573

Th. P. J van den Hout, "Khattushili III, King of the Hittites", in: J. M. Sasson (ed.), Civilizations of the Ancient Near East III (1995) 1107-20

F. C. Woudhuizen, "Luwian hieroglyphic monumental rock and stone inscriptions from the Hittite Empire Period", Talanta 26-27 1994-1995 (1996) 153-217 


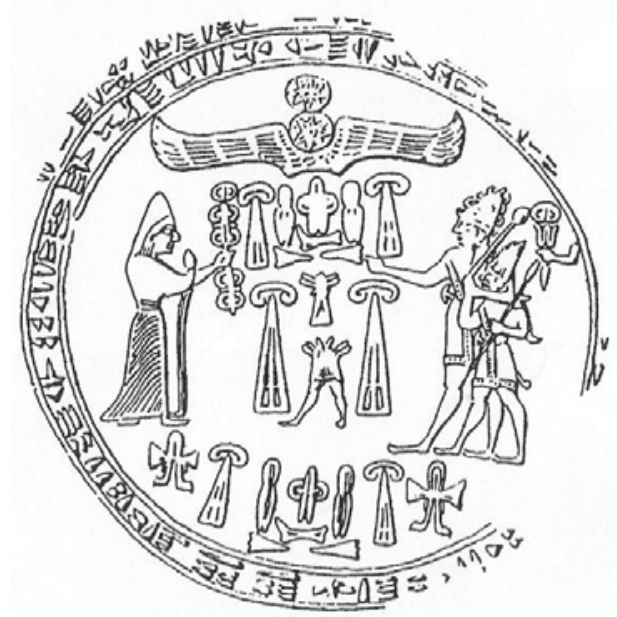

Şekil / Figure 1a

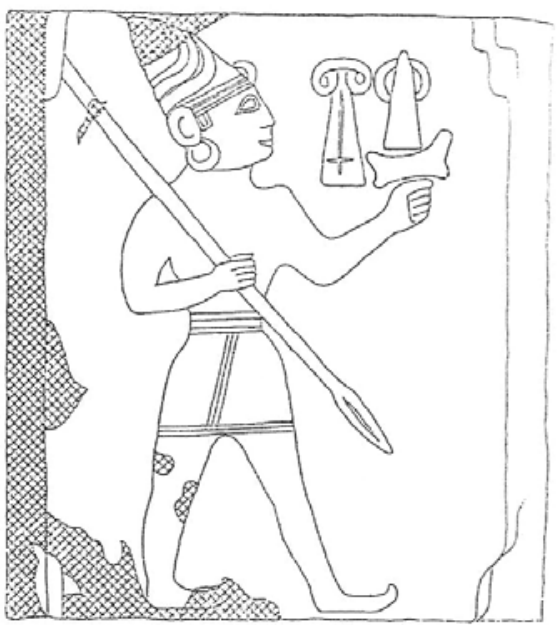

Şekil / Figure 3

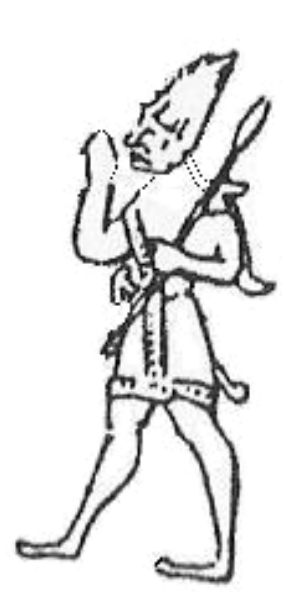

Şekil / Figure 1b

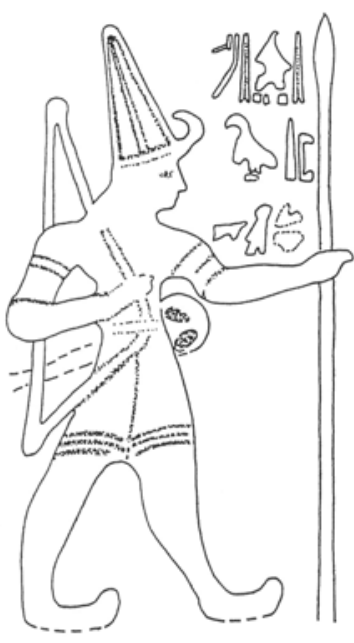

Şekil / Figure 4

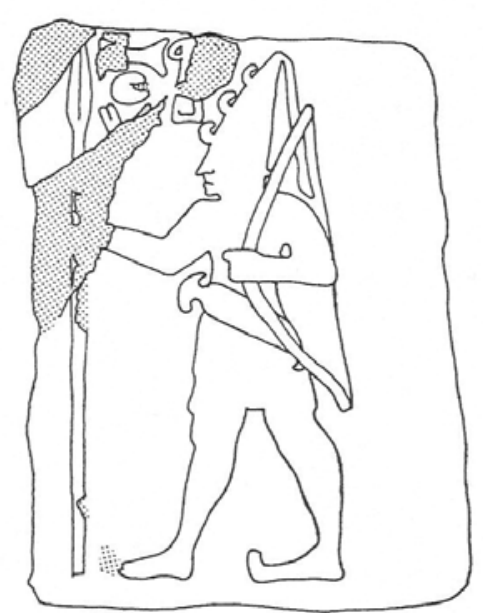

Şekil / Figure 2

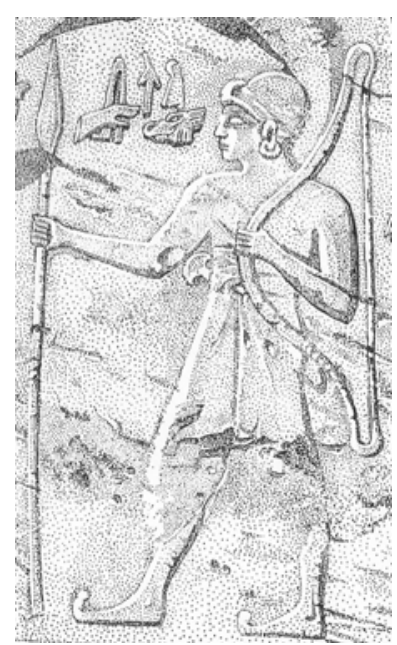

Şekil / Figure 5

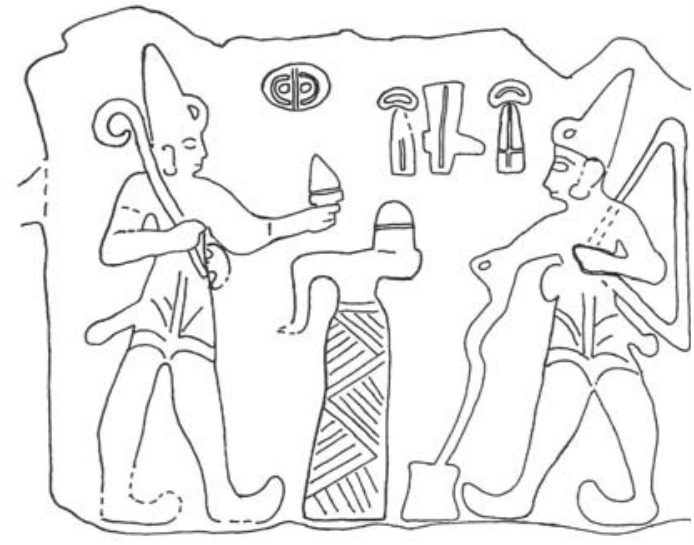

108

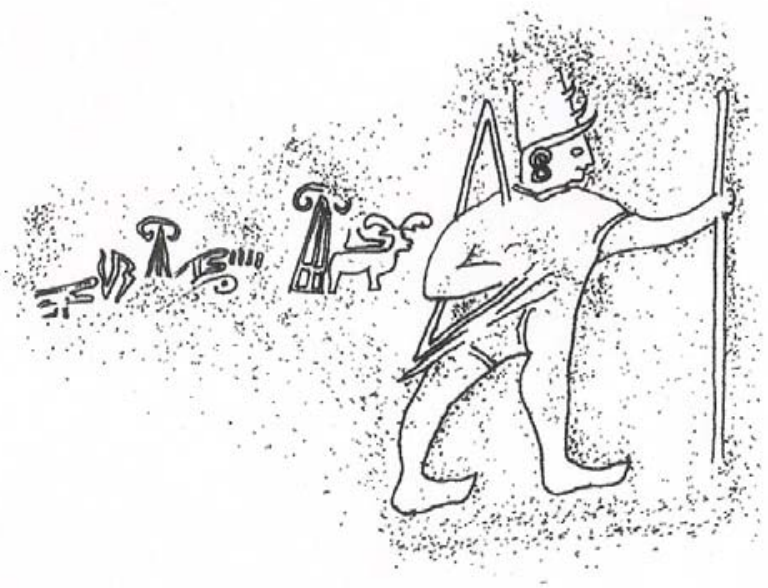

Şekil / Figure 7 


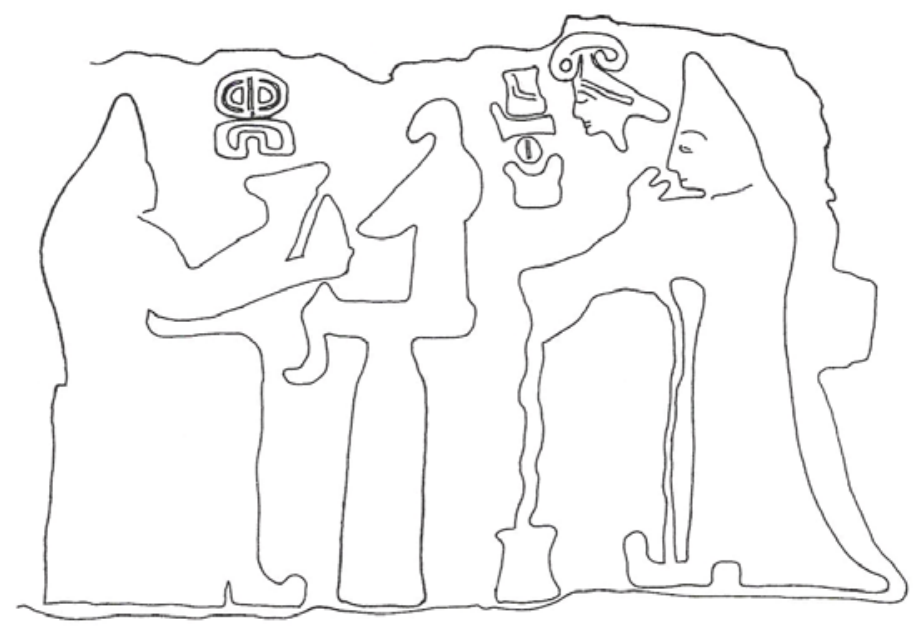

Şekil / Figure 8 